\title{
Exploring Health in Census 2011
}

\section{Frank Houghton, Sharon Houghton}

Dear Editor,

From a health perspective the Irish 2011 Census represents something of a mixed blessing. Its obvious limitations include the continuing absence of questions exploring both smoking ${ }^{1}$ and income, ${ }^{2}$ as well as the disappearance of the Census 2006 voluntary activity question. These questions could have helped direct health promotion efforts, measure and explore the health impacts of income inequality, and examine links between health and social capital/ social cohesion. ${ }^{3}$ Although some of this information has been captured via the Survey on Lifestyles, Attitudes \& Nutrition $\left(\mathrm{SLAN}^{4}\right)$, the Census facilitates the collection of such data on an almost universal level and includes valuable information at a local level. Inclusion of such personal questions may raise ethical issues in some quarters. However, it must be acknowledged that there appears to be little formal opposition to the Census in Ireland.

There are also a number of positive developments in relation to health in the 2011 Census that must be acknowledged. One such development has been the insertion of the age filter at a later point in the census form, so that it now appears after the question relating to Carers. In the last Census valuable data on the extent and burden of carers, and the relationship between these factors and the health of carers was collated. ${ }^{5}$ However, in 2006 due to the insertion of the age filter at an earlier stage on the Census form, data relating to Child Carers was missed. The UK Census of the same year however highlighted a significant number of children who performed the role of Carer. ${ }^{5}$ The alterations to the Irish census form should allow for the collection and collation of this data, which should in turn help to provide a better picture of the situation in relation to Irish Children who find themselves in the role of Carer.

As health researchers have come to expect, the Census will continue to ask questions about both long-term, restrictive conditions and their impact on activities of daily living.

Perhaps the most interesting new healthrelated development in the Census is the inclusion of a single-item global health measure. Many researchers will be familiar with items such as these via routine measures like the MOS SF-36, which includes a global measure in both versions ('In general, would you say your health is: Excellent; Very good; Good; Fair; Poor') ${ }^{6}$ Although such items may be contested, they can still provide a valuable, cost-effective, and virtually instantaneous insight into general wellbeing, and have been shown to be a robust predictor of mortality in longitudinal studies. ${ }^{7}$

The actual question (listed below) is a standard Organisation for Economic Cooperation and Development (OECD) measure that will facilitate international comparisons ${ }^{8}$ and includes a more balanced range of answers than the standard SF-36 measure given above:

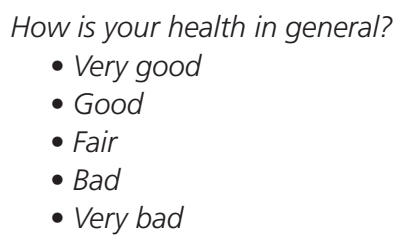

Although this question asks generically about health, it is clear that this type of question will undoubtedly be very useful in evaluating mental as well as physical health. A wide-ranging review conducted by Ware et al. for the Rand Corporation noted the significant relationship between such global measures and mental health constructs such as Happiness, Anomie, Life Satisfaction, and Self-Satisfaction ${ }^{9}$. More recent research has clearly confirmed this finding at local, national and international scales. ${ }^{10-11}$

Although other easy-to-complete measures which discriminate between mental and physical health exist, these are unlikely to be available at population level for Ireland in the near future. However, age, gender, and social class/educational level norms for the OECD general health question will be available shortly for Ireland. Therefore clinicians and researchers conducting research and evaluations into the future should seriously consider appending this single-item measure into their research to explore how this single-item measure maps across onto other conditions and domains.
Frank Houghton* Public Health Geographer \& Lecturer, Dept. of Humanities, Limerick Institute of Technology, Moylish, Limerick, Ireland

E-mail: Frank.Houghton@LIT.ie

Sharon Houghton, Dept. of Education \& Professional Studies, University of Limerick, Limerick, Ireland

\section{* Correspondence}

\section{References}

1. Houghton F. Smoking \& the Census - Need for an International Consensus. Aust N Z J Public Health 2001; 25(5): 478.

2. Houghton F. Census 2001 - Steps in the right direction, but still room for improvement. Ir Med J 2001; 94(6): 185

3. Harper R. The Measurement of Social Capital in the United Kingdom. London, Office for National Statistics; 2002.

4. Morgan K, McGee H, Watson D, Perry I, Barry M, Shelley E, Harrington J, Molcho M, Layte R, Tully N, van Lente E, Ward M, Lutomski J, Conroy R, Brugha R. SLÁN 2007: Survey of Lifestyle, Attitudes \& Nutrition in Ireland. Main Report. Dublin: Department of Health and Children, 2008.

5. Houghton F. The CSO, the Census and the needs of Carers. Irish Geography 2009; 42(3): 353-355.

6. Ware JE, Snow KK, Kosinski M, Gandek B. SF-36 Health Survey Manual and Interpretation Guide. Boston, MA: New England Medical Center, The Health Institute, 1993.

7. Idler EL, Benyamini Y. Self-rated health and mortality: a review of twenty-seven community studies. J. Health Soc Behav 1997; 38(1): 21-37.

8. OECD. Health at a Glance Europe: 2010. OECD Publishing; 2010. Accessed on September 30th 2011 at http://dx.doi.org/10.1787/health_glance-2010-en.

9. Ware JE, Davies-Avery A, Donald CA. Conceptualization and Measurement of Health for Adults in the Health Insurance Study: Vol. V, General Perceptions. Santa Monica, CA: Rand; 1978.

10. Marmot M, Wilkinson RG Social Determinants of Health. Oxford: Oxford University Press 2006

11. Berkman LF, Kawachi, I. Social Epidemiology. Oxford: Oxford University Press, 2000 